\title{
Sülfatlı Ortamda Kür Edilen Kireç - Alçı - Çimento Kompozit Malzeme Özelliklerinin Araştırılması
}

\author{
Gökhan GÖRHAN ${ }^{1 *}$, Beyza ÖZTEL², Fatma Nur KAZMACI ${ }^{3}$ \\ ${ }^{1,2,3}$ Afyon Kocatepe Üniversitesi, Mühendislik Fakültesi, Inşaat Mühendisliği Bölümü, Afyonkarahisar.
}

\author{
*Sorumlu yazar; e-posta: ggorhan@aku.edu.tr \\ bayzaaoztl@gmail.com \\ fatmanurk.07@gmail.com \\ ORCID ID: $h$ ttp://orcid.org/0000-0002-9925-1568 \\ ORCID ID: http://orcid.org/ 0000-0001-7163-9416 \\ ORCID ID: http://orcid.org/0000-0002-0482-0482
}

Anahtar kelimeler

Çimento; Alçı; Kireç; $\mathrm{MgSO}_{4} ; \mathrm{Na}_{2} \mathrm{SO}_{4}$.

Öz

Bu çalışmada çimento miktarının sabit (\% 40), alçı ve kireç malzemelerinin ise değişen oranlarda kullanıldığı kireç-alçı-çimento kompozit malzemeleri üretilmiştir. Kompozit malzemeler üretimi takiben sülfatlı çözeltilere maruz bırakılmış ve bu ortamlardan nasıl etkilendikleri araştııılmıştır. Örneklerin üretimi için hazırlanan karışımlarda; CL 80-S kalsiyum kireci, saten perdah alçısı ve CEM II/B-M (P-LL) $32.5 \mathrm{R}$ tipi çimento kullanılmıştır. Kalıplara yerleştirilen örnekler 2 gün boyunca laboratuvar ortamında muhafaza edilmiş, ardından kalıplardan alınan örnekler 7 gün süresince su kürüne maruz bırakılmıştır. Üretilen kompozit malzemelerin agresif ortam deneyleri için \% 2.5 ve \% $5^{\prime}$ lik $\mathrm{MgSO}_{4}$ ve $\mathrm{Na}_{2} \mathrm{SO}_{4}$ çözeltileri kullanılmıştır. 7 gün suda kür edilen numuneler ilgili çözeltilerde örneklerin yaşı 90 gün oluncaya kadar bekletilmiştir. Sonuç olarak hazırlanan kompozit malzemelerin $\mathrm{Na}_{2} \mathrm{SO}_{4}$ etkisinden daha az etkilendiği bununla birlikte $\mathrm{Na}_{2} \mathrm{SO}_{4}$ çözeltisine maruz kalan örneklerin basınç dayanımlarının 8.8-12.2 $\mathrm{MPa} \mathrm{MgSO}_{4}$ çözeltisine maruz kalan örneklerin basınç dayanımlarının ise 4.1 - 9.1 MPa arasında değişkenlik gösterdiği tespit edilmiştir. Aynı zamanda $\mathrm{MgSO}_{4}$ etkisine maruz kalan kompozit malzemelerde, \% 30 oranında kireç kullanılması durumunda referans örneklerden daha yüksek basınç dayanım değerleri elde edildiği gözlenmiştir.

\section{Investigation of Properties of Lime - Gypsum - Cement Composite Material Cured in Sulphate Medium}

\begin{abstract}
In this study, lime-gypsum-cement composite materials were produced in which fixed cement amount was used (40\%) and gypsum and lime materials were used in varying proportions. Produced composite materials were exposed to sulphate solutions and investigated how they were affected by these environments. In the mixtures prepared for the production of the samples; CL 80-S calcium lime, satin plaster and CEM II/B-M (P-LL) 32.5 R type cement were used. Samples placed in the moulds were kept in laboratory for 2 days, and then samples taken from the moulds. After that, these samples were exposed to water curing for 7 days. $2.5 \%$ and $5 \% \mathrm{MgSO}_{4}$ and $\mathrm{Na}_{2} \mathrm{SO}_{4}$ solutions were used for aggressive media tests of the produced composite materials. Samples which were cured in 7 days water were kept in the related solutions until 90 days of age. As a result, the composite materials were less affected by the $\mathrm{Na}_{2} \mathrm{SO}_{4}$ effect, however, the compressive strength of the samples exposed to $\mathrm{Na}_{2} \mathrm{SO}_{4}$ solution was 8.8 - 12.2 MPa and It was determined that the compressive strength of the samples exposed to $\mathrm{MgSO}_{4}$ solution varied between 4.1 and $9.1 \mathrm{MPa}$. In the case of composite materials which have been exposed to $\mathrm{MgSO}_{4}$ effect, a better compressive strength value is obtained from the samples according to the reference samples when $30 \%$ lime is used.
\end{abstract}

Keywords

Cement; Gypsum; Lime $\mathrm{MgSO}_{4} ; \mathrm{Na}_{2} \mathrm{SO}_{4}$. 


\section{Giriş}

Yapılarda kullanılan malzemeler servis ömrü boyunca farklı etkilere ve koşullara maruz kalabilmektedir. Bu koşullar içerisinde yer alan etkiler; kimyasal, fiziksel ve fiziko-kimyasal etkiler olarak sıralanabilmektedir. Beton malzemesi başta olmak üzere kimyasal saldırılar altında kalan malzemelerde bozulmalar ve geçirimlilik artmaktadır. Bu etkilerin zararlarını en aza indirmek için malzemenin geçirimliliğini azaltmak ve değişik puzolan katkılı çimentoların kullanılması akla gelen ilk tedbirler arasında yer almaktadır (Eren 2009).

Bahsedilen etkiler içerisinde yer alan sülfat saldırısı sonucunda ise çimento harçlarında genleşme ve çatlaklarla ilgili bazı problemler ortaya çıkabilmektedir (Eren 2009).

Sülfat etkisi temelde, sülfat iyonları ile kalsiyum alüminat hidrat ve kalsiyum hidroksit arasında meydana gelen ve betonda genleşme oluşturan ürünlerin ortaya çıkmasına sebep olan bir reaksiyondur (Ilıca 2008). Özellikle yer altı suları ve killi topraklarda sülfat tuzları $\left(\mathrm{MgSO}_{4}\right.$ ve $\left.\mathrm{Na}_{2} \mathrm{SO}_{4}\right)$ bulunabilmektedir. Genelde beton içerisine sızan sularla birlikte nüfuz eden sülfatlar, malzemenin genleşip çatlamasına ve doğal olarak hasar görmesine yol açmaktadır. Hatta sülfatların beton malzemelerde oluşturduğu yıpratıcı etkiye sülfat hücumu adı verilmektedir. Bu yıpratıcı etkiye çoğunlukla temel betonlarında, istinat duvarlarında ve kanal kaplama boruları gibi yapı elemanlarında sıkça rastlanılmaktadır. Sülfatların bulunduğu sular ile sertleşmiş çimento bünyesinde gerçekleşen reaksiyonlar sonucu bünyede alçıtaşı oluşumu ve kalsiyum-alümino-monosülfohidratın da bu malzeme ile tekrar reaksiyona girmesi sonucunda etrenjitin ortaya çıkmasına sebep olarak malzemenin stabilitesini bozacak genleşmeler ortaya çıkabilmektedir (Erdoğan 2003).

Yapıları ve yapı elemanlarını korumak adına kullanılabilen harçlar, yapıların servis ömrünü önemli derecede etkileyen ve çok yaygın olarak kullanılan yapı malzemelerinden birisidir (Huang et al. 2018). Bu nedenden dolayı günümüze kadar geçen süre içerisinde inşa edilen yapıların mevcut ortam koşullarından zarar görmemesi adına sıva uygulamaları yapılmıştır. Özellikle tarihi yapılarda sıva olarak kullanılan harçlarda; kireç, alçı v.b. gibi malzemeler bağlayıcı olarak kullanılmıştır (Aktürk vd. 2017).

Harçlarda sıklıkla kullanılan malzemelerden biri olan kireç, kireç taşının pişirilmesinin ardından harç üretiminin en önemli bileşenlerinden birisi haline gelmiştir (Tekin ve Kurugöl 2012). Bununla birlikte, çimento ve kireç içerikli harçlar, yapı alanında tercih edilen en popüler malzemelerden birini oluşturmaktadır (Nayaka et al. 2018). Kireç malzemesinin mevcut piyasada erişiminin kolay olması ve bu ürünün fiyatının düşük seviyelerde yer alması nedeniyle sık tercih edilen bir malzemedir. Hava kirecinin çimento hidratasyonunu hızlandırdığı, gözenekliliği arttırdığı ve dayanımı azalttığı da bilinmektedir (Jaafri et al. 2019).

Kireç bazı harçlar çok uzun yıllardır ve özellikle Roma imparatorluğu döneminde sıkça tercih edilmiştir. Hatta Romalı mimarlar tarafından kireç harcı karışımları için temel kurallar ortaya çıkarılmış (Nayaka et al. 2018) ve harç teknolojisi geliştirilerek kireç-kum ve kireç-alçı karışımlı harçların uygulama alanları genişletilmiştir (Tekin ve Kurugöl 2012).

Belli bir süre boyunca kireç esaslı harçlar yapılarda kullanım alanı bulmuştur. Çimento esası harçların daha hızlı dayanım gelişimi göstermesi ve yüksek mukavemetlerinden dolayı kireç harçlarının yerini almıştır. Fakat bu tip harçlarda eski kâgir elemanlar üzerinde uyumsuzluk oluşturabilecekleri, hidratasyon döngüleri neticesinde taş üzerinde kullanılmaları durumunda taşa zarar verecek yüksek tuz içeriğine sahip olması ve ısı etkileri sonucunda oluşacak durumlarda düşük esneklik kapasitesinin olması önemli dezavantajlar olarak gözükmektedir. Dolayısıyla bu tip harçların tarihi yapılarda kullanılması durumunda bazı sıkıntıların ortaya çıkması muhtemeldir (Arandigoyen and Alvarez 2007).

Harçların özelliklerinin geliştirilmesi adına yapılan çalışmalarda üretilen harçların durabilite ve boyutsal stabilitesinin çimentoya eklenen filler malzemeler ile önemli oranda etkilendiği tespit edilmiştir (Li et al. 2018). Çimentoya filler ikamesi ile birlikte çimento içeriği azalmakta ve bu azalma ile birlikte su/çimento oranı artmaktadır. Bu sebeple 
Sülfat/ı Ortamda Kür Edilen Kirec - Alç - Cimento Kompozit Malzeme Özelliklerinin Araștırılması, Görhan vd.

yüksek ikame oranları, örneklerde durabilitenin ve stabilitenin bozulmasına yol açabilir (Li et al. 2018). Bunun yanında, temelde yüksek oranlarda kireçtaşı filler, betonda kullanıldığı zaman ortamda yüksek nem ve düşük sıcaklık varsa ve eğer örnekler sülfat ataklarına maruz kalırsa bünyede tomasit formları oluşabilir (Lee et al. 2008). Bu formlar kompleks hidratlardır ve yer altı suyunda bulunan sülfat iyonlarının portland çimentosu ve kireçtaşı agregasının etkileşimiyle oluşurlar (Hartshorn et al. 1999).

Normal koşullarda sülfat iyonları pasta içerisindeki kalsiyum hidroksiti, etrenjit ve alçı taşına dönüştürür (Wongprachum et al. 2018). Katyon tipine bağlı olarak $\mathrm{Mg}(\mathrm{OH})_{2}, \mathrm{NaOH}$ gibi hidroksitlerde oluşmaktadır. Bunlarda sülfatın etki mekanizmasını önemli derecede etkiler dolayısıyla sülfat iyonunun etkisi katyon tipinden bağımsız değildir (Güneyisi vd. 2007). Bu ürünlerin şişmesi nedeniyle, içte gerilme genişler ve yüzeyde çekme gerilmeleri oluşturur. Çözelti içerisinde gerilmelerin sürekli artmasıyla birlikte maruz kalınan süre uzadıkça bozulma derecesi de artmaktadır (Wongprachum et al. 2018).

Kireçtaşı tozunun çimentoya ikame edilmesi durumunda ise, pasta ve harçlarda bulunan ikame oranlarının daha yüksek seviyelerde olmasının sülfat ataklarına karşı örnekleri daha duyarlı hale getirdiği belirtilmektedir (Li et al. 2018).

Çimento üretiminde de kullanılan malzemelerden biri olan alçı ise günümüzde ısı ve ses yalıtımı için iyi özellikler gösteren bir malzeme olmasının yanında çimento ve kireç esaslı malzemelere kıyasla ucuz bir malzemedir. Fakat alçı, su ile temas ettiğinde kısmen ayrışan bir malzemedir. Bu nedenle su ile alçının teması halinde malzemenin mukavemeti de azalmaktadır (Yıldız vd. 2006). Alçı maliyet açısından çimento ve kireç esaslı malzemelere göre daha ekonomik olmasının yanında yalıtım, hafiflik ve işleme kolaylığı açısından rahat bir malzeme grubudur. Bununla birlikte alçı dayanıksız bir malzeme olduğundan yapılarda dış etkilere maruz kalan yerlerde kullanılmamalıdır (Akın vd. 2013).
Bahsedilen bilgilerin yanında şu ana kadar yapılan çalışmalarda, harç üretiminde kullanılan kumun granülometrik bileşiminin harç reolojisi üzerine etkisinin incelendiği (Stolz and Masuero 2018) ve harç kalınlığının eğilmede çekme dayanımına etkisinin incelendiği (Huang et al. 2018) araştırmalar bulunmaktadır. Harçların sülfatlı ortamlardaki davranışları ile ilgili bazı çalışmalar yapıımış olup yapılan çalışmalardan birinde lif katkılı çimento harçları \% $5 \mathrm{NaSO}_{4}$ çözeltisine 4 ve 8 ay süre ile maruz bırakılmıştır ve bu ortama maruz kalan örneklerde ağırlık kaybı gözlenmiştir (Wongprachum et al. 2018). Bunun yanında kireç esaslı duvar tamir harçları ile ilgili çalışmalara da rastlanılmaktadır (Moropoulou et al. 2005; Lanas et al. 2003).

Yapılan bu çalışmada ise genel olarak duvar yüzeyine uygulanması düşünülen kompozit bir sıva pastası oluşturulmuştur. Bu kompozit sıva pastasında çimento miktarının sabit, alçı ve kireç gibi malzemelerin ise değişen oranlarda kullanıldığı malzemeler üretilmiştir. Bu malzemelerin sülfat etkisine maruz kalabilecek duvar yüzeylerinde kullanılmaları durumunda ilgili ortamdan nasıl etkilendiklerini belirleyebilmek amacıyla belli süreler için sülfatlı çözeltilere maruz bırakılmış ve sonuçta bu ortamlardan nasıl etkilendikleri araştırılmıştır.

\section{Materyal ve Metot}

\subsection{Kullanılan Malzemeler}

Örneklerin üretimi için hazırlanan karışımlarda; TS EN 459-1'e uygun olarak üretilen CL 80-S kalsiyum kireci, saten perdah alçısı ve CEM II/B-M (P-LL) 32.5 $\mathrm{R}$ tipi portland kompoze çimentosu kullanılmıştır. $\mathrm{Bu}$ çimentoda katkı maddesi olarak tras bulunmakta olup kalkerde toplam organik muhtevası kütlece maksimum \% 0.2'dir (TS EN 197-1 2002). Bu bağlayıcılardan oluşan karışımın plastikliğini sağlamak amacıyla yapılan ön denemeler ve optimizasyon çalışmaları sonucuna göre belli bir oranda su ilavesi yapılmıştır. Üretilen kompozit örneklerin agresif ortam deneyleri için $\mathrm{MgSO}_{4} * 7 \mathrm{H}_{2} \mathrm{O}$ $(\mathrm{M}=246,48 \mathrm{~g} / \mathrm{mol})$ ve $\mathrm{Na}_{2} \mathrm{SO}_{4}(\mathrm{M}=142,04 \mathrm{~g} / \mathrm{mol})$ kimyasalları kullanılmıştır. 
Sülfatlı Ortamda Kür Edilen Kirec - Alcı - Cimento Kompozit Malzeme Özelliklerinin Araștırılması, Görhan vd.

Çimentonun kimyasal analizleri dikkate alınarak hesaplanan Bogue denklemlerine göre ilgili çimentoda bulunan $\mathrm{C}_{3} \mathrm{~A}$ oranı \% 7.31 olarak hesaplanmıştır. ASTM standartlarına göre sülfata dayanıklı çimentolarda ise $C_{3} A$ oranının $\% 4-\% 6$ arasında olduğu belirtilmektedir (Erdoğan 2003). Bu çalışmada kullanılan çimento aynı zamanda Gümüş'ün (Gümüş 2016) çalışmasında da kullanılmış olup malzemeye ait XRF analiz değerleri Çizelge 1'de verilmiştir. Çimento malzemesine ait kimyasal analiz değerleri dikkate alındığında malzeme bünyesinde $\mathrm{SO}_{3}$ oranı \% 3.57'dir. Buna göre çimento bünyesinde bulunan ve çimentodan kaynaklı $\mathrm{CaSO}_{4}$ miktarı yaklaşık \% 6.07 olarak hesaplanabilmektedir (Erdoğan 2003).

Çizelge 1. CEM II/B-M (P-LL) $32.5 \mathrm{R}$ tipi çimentonun kimyasal kompozisyonu.

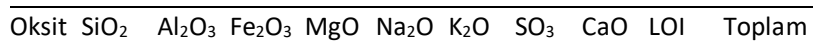
\begin{tabular}{lllllllllll}
\hline$\%$ & 14.52 & 4.08 & 2.07 & 3.53 & 0.61 & 1.12 & 3.57 & 56.6 & 13.23 & 99.33
\end{tabular}

\section{2 Örneklerin Hazırlanması ve Uygulanan Testler}

Referans reçetelerin oluşturulmasında Çizelge 2'de verilen oranlara göre malzemeler, laboratuvar tipi otomatik programlanabilir çimento mikserinde TS EN 196-1'e (2016) göre karıştırılmıştır. Karıştırma işlemlerinde öncelikle kuru halde bulunan bağlayıcı malzemeler $30 \mathrm{sn}$. süre ile karıştırılmış ardından su, hazırlanmış olan kuru karışıma ilave edilerek $60 \mathrm{sn}$. daha karıştırma işlemine devam edilmiştir. Karıştırma hızı ise karıştırma kabı yörüngesinde 62 devir/dakika olarak ayarlanmıştır.

Çizelge 2. Kullanılan malzemeler ve oranları.

\begin{tabular}{ccccc}
\hline \multirow{2}{*}{$\begin{array}{c}\text { Örnek } \\
\text { kodu }\end{array}$} & \multicolumn{3}{c}{ (\%) } & $\begin{array}{c}\text { Su/Bağlayıcı } \\
\text { oranı }\end{array}$ \\
\cline { 2 - 4 } & Kireç & Alçı & Çimento & 0,4 \\
RÇ-1 & 50 & 10 & 40 & 0,4 \\
RÇ-2 & 40 & 20 & 40 & 0,4 \\
RÇ-3 & 30 & 30 & 40 & \\
\hline
\end{tabular}

Otomatik programlanabilir çimento mikserinde karıştırılan örnekler akabinde $50 \times 50 \times 50$ mm³ lük metal kalıplara yerleştirilmiştir. Yerleştirme işleminde titreşimli (vibrasyonlu) sehpa kullanılmıştır. Örneklerin hazırlanmasında çimento miktarı ağırıkça \% 40 oranında ve sabit tutulmuştur. Karışım suyu (Su/bağlayıcı) miktarları ise kireç, alçı ve çimento malzemelerinin toplam ağırlığının \% 40'ı olarak alınmıştır. Referans örnekler üretimlerini takiben 90 gün süre ile normal suda kür edilmiştir.

Sülfat etkisine maruz bırakılacak örnekler, öncelikle 2 gün boyunca laboratuvar ortamında kalıplarda muhafaza edilmiştir. Ardından kalıplardan alınan örnekler 7 gün süresince su kürüne maruz bırakılmıştır. Agresif ortam etkilerini belirleyebilmek amacıyla Çizelge 3'de verildiği gibi her bir çözelti grubu için 3'er adet örnek kullanılmıştır. Sülfat iyonlarının örnekleri nasıl etkileyeceğini belirlemek için 7 günlük örnekler, üretimlerini takiben 90 gün süre ile sülfat çözeltilerine maruz bırakılmıştır. Sülfat çözeltisi oranları ASTM C1012 (2018) dikkate alınarak öncelikle \% 5 alınmış ardından da bu değerin yarısını temsil edecek şekilde \% 2.5 oranı kullanılmıştır. Bununla birlikte ASTM C1012 (2018) standardına göre katkılı çimentolar için sülfat çözeltisine yerleştirme şartları (örnek yaşı ve kazandığı basınç dayanımı) bu çalışmada verilen durumdan farklılık göstermektedir.

Çizelge 3. Kimyasal malzemeler ve oranları.

\begin{tabular}{ccc}
\hline $\begin{array}{c}\text { Örnek } \\
\text { kodu }\end{array}$ & $\begin{array}{c}\text { Çözelti oranı } \\
\text { (Ağırlıkça) (\%) }\end{array}$ & $\begin{array}{c}\text { Sülfat } \\
\text { (Kimyasal) } \\
\text { tipi }\end{array}$ \\
\hline $2 \mathrm{~N}$ & 2,5 & $\mathrm{Na}_{2} \mathrm{SO}_{4}$ \\
$5 \mathrm{~N}$ & 5 & $\mathrm{Na}_{2} \mathrm{SO}_{4}$ \\
$2 \mathrm{M}$ & 2,5 & $\mathrm{MgSO}_{4}$ \\
$5 \mathrm{M}$ & 5 & $\mathrm{MgSO}_{4}$ \\
\hline
\end{tabular}

Referans ve agresif ortam çözeltilerine maruz kalan toplam 15 seri kompozit malzeme örnekleri üzerinde Arşimet prensibi ile TS EN 772-4 (2000)'e (görünen porozite ve birim hacim ağırlık) ve TS EN 771-1 (2005)'e (ağırlıkça su emme) göre bazı fiziksel özellikler belirlenmiş ardından da mekanik özelliklerden biri olan basınç dayanım testleri ise TS EN 196-1 (2016)'e göre gerçekleştirilmiştir. Son olarak örneklerin içyapılarının daha iyi anlaşılabilmesi amacıyla seçilen örnekler üzerinde SEM-EDX analizleri ile XRD analizleri $\left(2 \theta=85^{\circ}\right.$ ye kadar) uygulanmıştır.

\section{Bulgular ve Tartışma}

Fiziksel özellikler açısından üretilen kompozit malzemelerin özellikleri dikkate alındığında, ilgili örneklerin bünyesinde bulunan alçı oranlarının 
Sülfat/ı Ortamda Kür Edilen Kirec - Alç - Cimento Kompozit Malzeme Özelliklerinin Araștırılması, Görhan vd.

artması görünen porozite oranları üzerinde

değişken sonuçlar vermiştir (Şekil 1a ve b). Referans örneklerin görünen porozite oranları \% 47.8 - \% 50.4 arasında değişirken; $\mathrm{Na}_{2} \mathrm{SO}_{4}$ ve $\mathrm{MgSO}_{4}$ çözeltisine maruz kalan kompozit malzemelerde porozite oranlarının azaldığı gözlenmiştir. Literatürde kireç-çimento karışımlarında kullanılan kirecin oranı arttığında porozitenin de arttığı gözlenmiştir. Aynı zamanda su/bağlayıcı oranına bağlı olarak porozitenin \% 50 - \% 65 arasında değiştiği belirtilmiştir (Arandigoyen and Alvarez 2007). Bu noktada elde edilen değerler literatürde verilen değerlere yakınlık göstermektedir.

Bununla birlikte $\quad \mathrm{Na}_{2} \mathrm{SO}_{4} \quad$ çözeltisi konsantrasyonunun \% 5 olduğu örneklerde ise porozite değerleri tüm gruplar içerisinde ki en düşük değerleri almıştır (Şekil 1a). Aynı zamanda $\mathrm{MgSO}_{4}$ çözeltisine maruz kalan örneklerde ise \% 5 çözelti konsantrasyonunda kalan örneklerde de yakın gözeneklilik oranları elde edilmesinin yanında bünyede bulunan alçı oranının artması ile birlikte görünen porozite oranlarının bir nebze arttığı gözlenmiştir (Şekil 1b).

Porozitede oluşan azalmaların alçı ile sülfat çözeltileri arasındaki reaksiyonlar sonucu bünyede ilave ürünlerin ortaya çıkarak boşluklu yapıları doldurmasının neticesi olduğu düşünülmektedir. Nitekim çimento bünyesinde bulunan $\mathrm{C}_{4} \mathrm{AF}$ ve sülfatlar arasındaki reaksiyonların neticesinde etrenjit oluşacağı; ancak oluşan etrenjitin amorf yapıda olması nedeniyle genleşme hasarı oluşmasının beklenmediği de belirtilmektedir (Ilıca 2008).
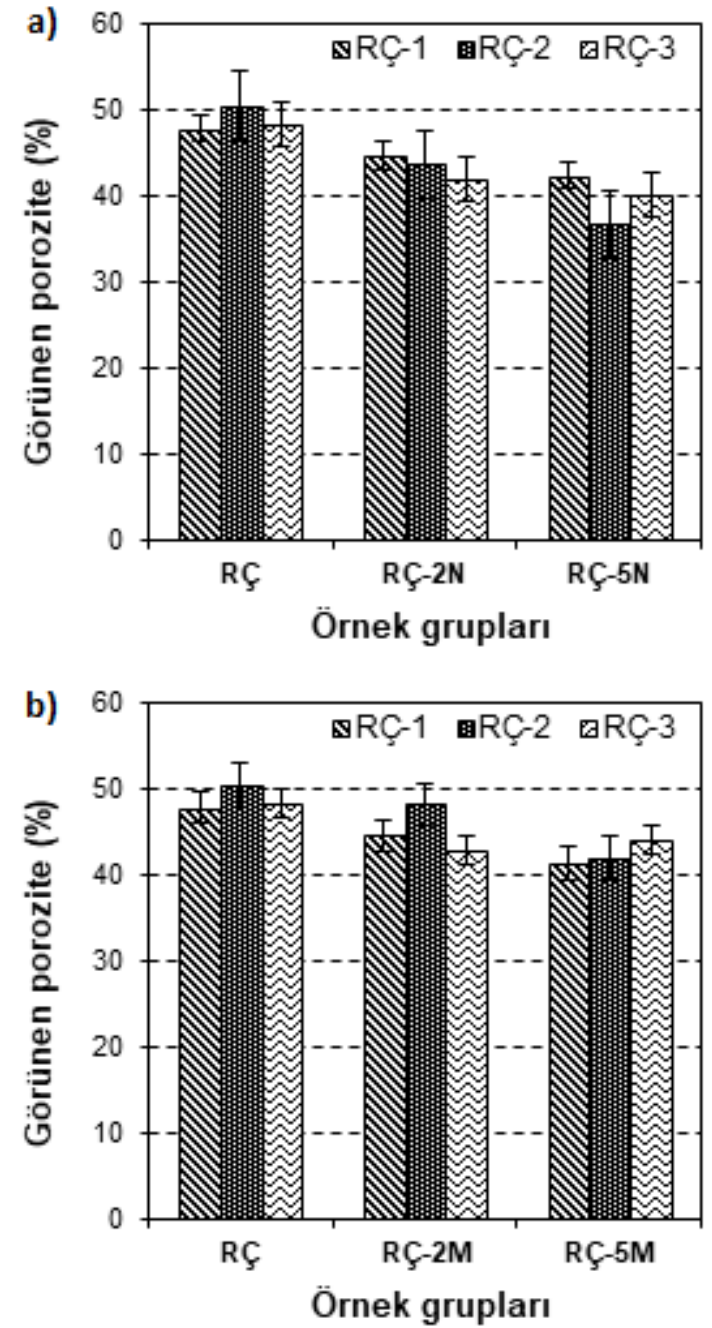

Şekil 1. a) $\mathrm{Na}_{2} \mathrm{SO}_{4}$ etkisine, b) $\mathrm{MgSO}_{4}$ etkisine maruz kalan örneklerin görünen porozite oranları.

$\mathrm{Bu}$ literatür bilgisinin yanında çalışmada üretilen örneklerin bünyesinde çimento oranının \% 40 seviyesinde tutulması nedeniyle $\% 10$ ve $\% 20$ alçı içerikli örneklerin XRD analiz grafiklerinde, $2 \theta=2^{\circ}$ $85^{\circ}$ arasında yapılan analizlerden görüleceği üzere malzeme bünyesinde kristal yapılı bir etrenjit oluşumuna rastlanmamıştır (Şekil 2).

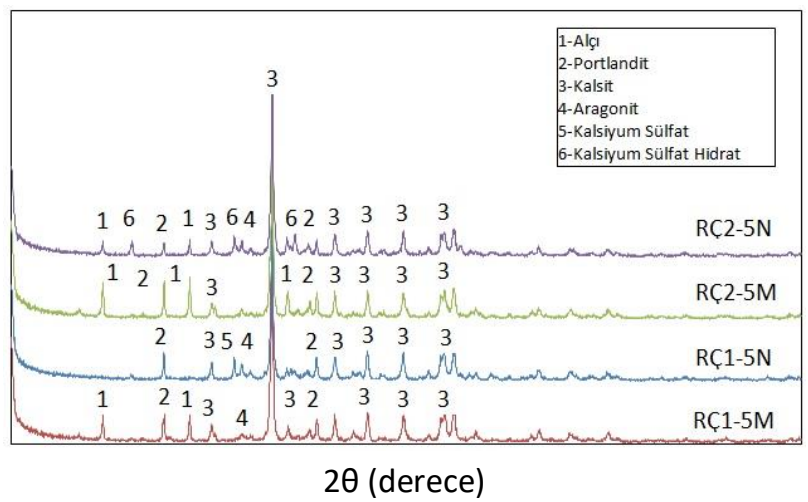

Şekil 2. Örneklere ait XRD difraktogramı. 
Sülfatlı Ortamda Kür Edilen Kirec - Alcı - Cimento Kompozit Malzeme Özelliklerinin Araștırılması, Görhan vd.

Bununla birlikte sülfat etkisine maruz bırakılan örneklerin bünyesinde kolloidal amorf yapılı etrenjit oluşumu gerçekleşmiş olabilir. Bu doğrultuda, örneklerin yüzeylerinde ve \% 30 alçı içerikli RÇ3 örneklerinin çekilen SEM (500x) görüntülerinde de örneklerde genleşme hasarı gözlenmemiştir (Resim 1 ve Resim 2).

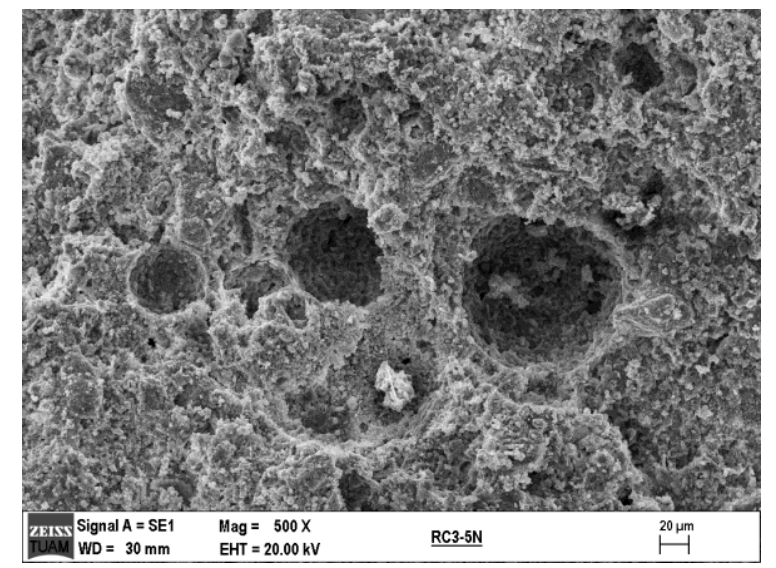

Resim 1. RÇ3-5N örneğine ait SEM görüntüsü.

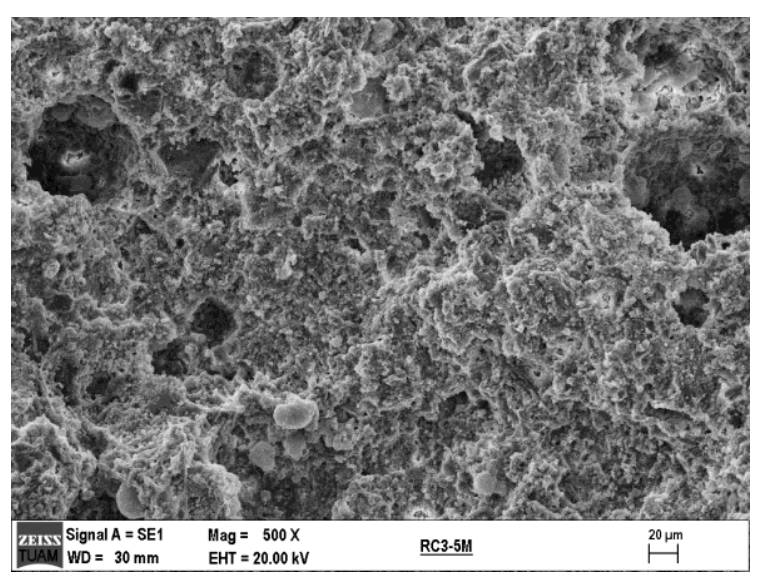

Resim 2. RÇ3-5M örneğine ait SEM görüntüsü.

Çizelge 4. SEM-EDX analiz sonuçları (\%).

\begin{tabular}{lccccc} 
Örnek & $\mathrm{SiO}_{2}$ & $\mathrm{Al}_{2} \mathrm{O}_{3}$ & $\mathrm{MgO}$ & $\mathrm{SO}_{3}$ & $\mathrm{CaO}$ \\
\hline RÇ3-2N & 8.84 & 1.54 & 1.07 & 21.25 & 67.30 \\
RÇ3-5N & 7.23 & 0.70 & 0.24 & 25.73 & 66.10 \\
RÇ3-2M & 8.25 & 1.21 & 0.80 & 26.29 & 63.45 \\
RÇ3-5M & 8.26 & 0.91 & 0.32 & 24.48 & 66.03 \\
\hline
\end{tabular}

Malzemelerden RÇ3-2N, RÇ3-5N, RÇ3-2M, RÇ3-5M kodlu örneklerin SEM-EDX analizleri (Çizelge 4) incelendiğinde; temel olarak magnezyum, alüminyum, silis, sülfür ve kalsiyum gibi elementlerin varlığı gözlenmiştir. Ayrıca $\mathrm{Na}_{2} \mathrm{SO}_{4}$ çözeltisine maruz kalan örneklerdeki $\mathrm{SO}_{3}$ oranının, $\mathrm{MgSO}_{4}$ çözeltisine maruz kalan örneklere kıyasla bir miktar daha düşük seviyelerde olduğu belirlenmiştir.
Referans örneklerin porozite oranlarında oluğu gibi, su emme oranları da $\mathrm{Na}_{2} \mathrm{SO}_{4}$ ve $\mathrm{MgSO}_{4}$ çözeltisine maruz kalan örneklerden daha yüksek seviyelerdedir. $\mathrm{Na}_{2} \mathrm{SO}_{4}$ çözeltisine maruz kalan örneklerde su emme oranları \% 26.8 - \% 33.3 oranları arasında değişkenlik gösterirken (Şekil 3a); $\mathrm{MgSO}_{4}$ çözeltisine maruz kalan örneklerde bu oranlar \% 30.2 - \% 40.5 arasında değişmiştir (Şekil $3 b)$. Elde edilen bu veriler dikkate alındığında $\mathrm{MgSO}_{4}$ çözeltisine maruz kalan kompozit malzemelerde nispeten daha yüksek oranlarda su emmenin gerçekleştiği tespit edilmiş olup, kompozit malzeme bünyesinde bulunan alçı-kireç oranlarındaki değişimlerin sonuçlar üzerinde lineer bir etki oluşturmadığı gözlenmiştir.
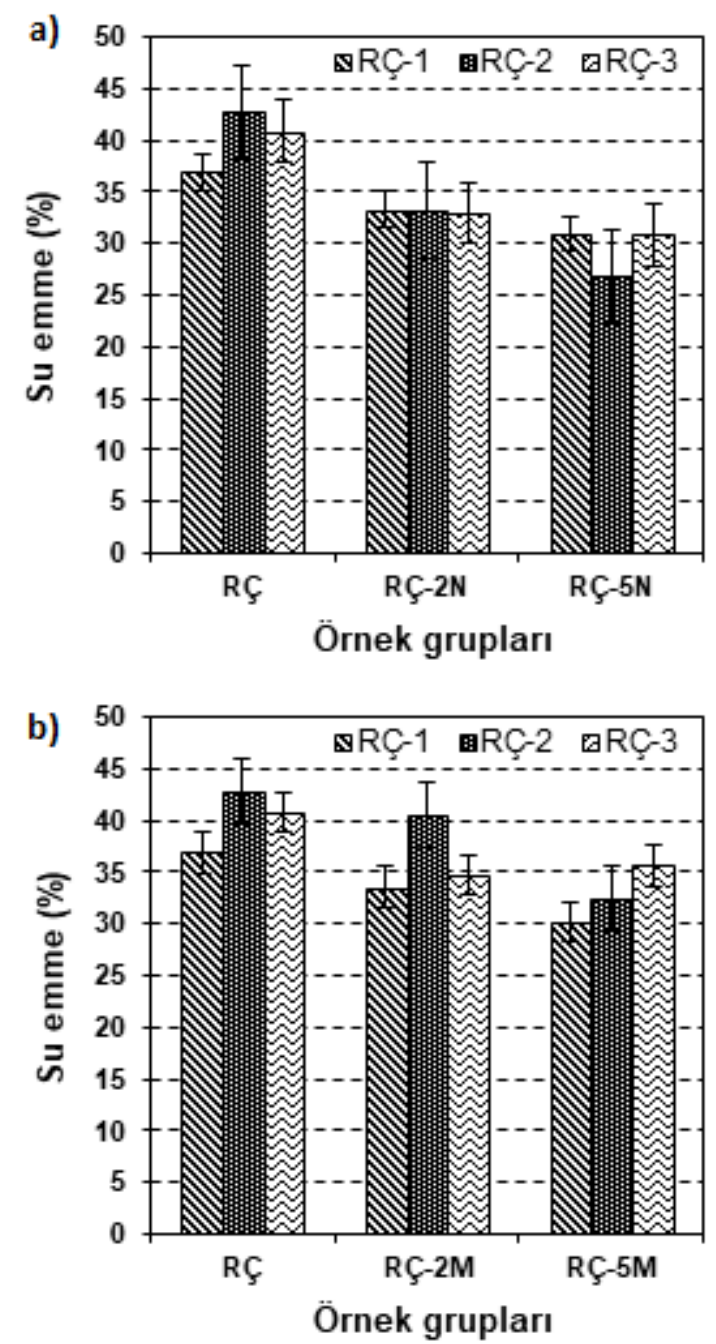

Şekil 3. a) $\mathrm{Na}_{2} \mathrm{SO}_{4}$ etkisine, b) $\mathrm{MgSO}_{4}$ etkisine maruz kalan örneklerin su emme oranları.

Sülfat çözeltilerine maruz kalan kompozit malzemelerin birim hacim ağıllıkları referans örneklerden daha yüksek değerlere ulaşmıştır. 
Sülfatlı Ortamda Kür Edilen Kirec - Alcı - Cimento Kompozit Malzeme Özelliklerinin Araștırılması, Görhan vd.

$\mathrm{Na}_{2} \mathrm{SO}_{4}$ ve $\mathrm{MgSO}_{4}$ çözelti konsantrasyonunun \% 5 olduğu örneklerde ise birim hacim ağırlık değerleri en yüksek seviyelere ulaşmıştır. Bu noktada bünye içerisinde bulunan alçı oranın \% 20 olduğu ve \% 5 $\mathrm{Na}_{2} \mathrm{SO}_{4}$ çözeltisine maruz kalan kompozit malzemelerde $1386.7 \mathrm{~kg} / \mathrm{m}^{3}$ (Şekil 4a); yine alçı oranın \% 10 olduğu ve \% $5 \mathrm{MgSO}_{4}$ çözeltisine maruz kalan kompozit malzemelerde ise $1366.3 \mathrm{~kg} / \mathrm{m}^{3}$ (Şekil 4b) ile en yüksek birim hacim ağırlık değerlerine ulaşılmıştır.
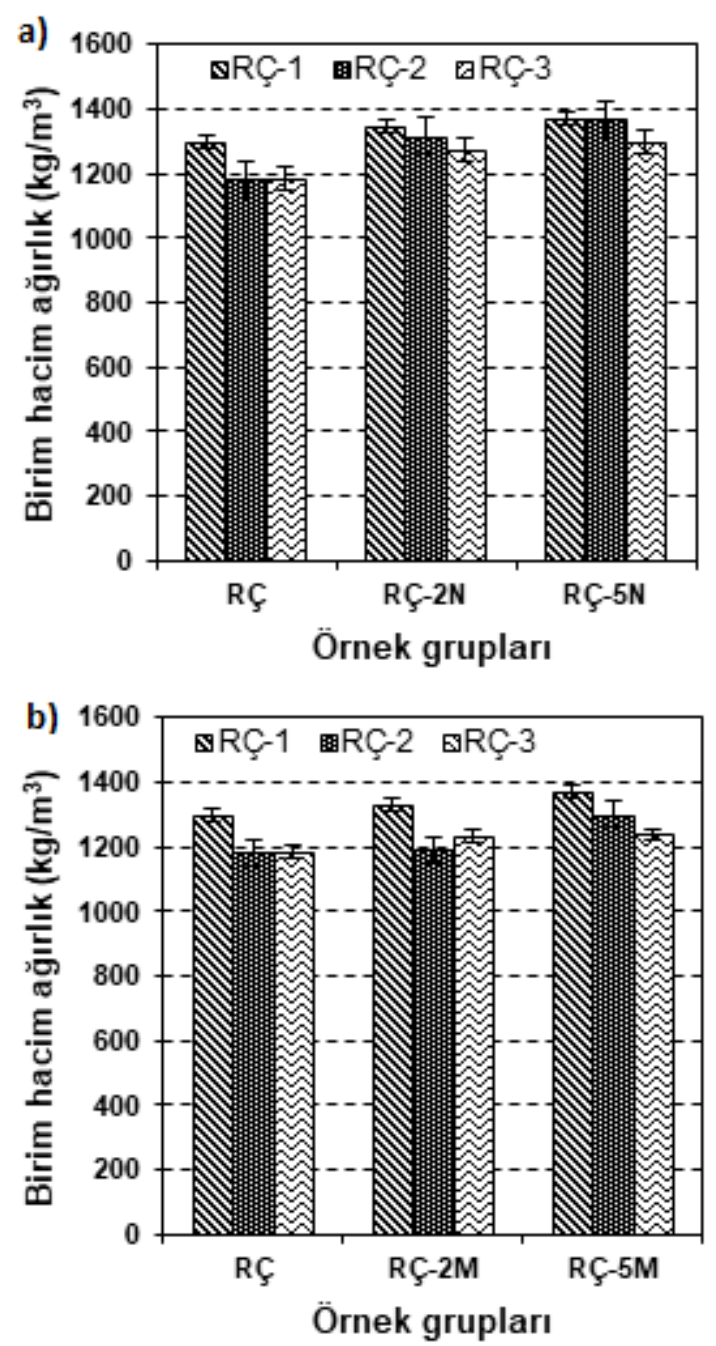

Şekil 4. a) $\mathrm{Na}_{2} \mathrm{SO}_{4}$ etkisine, b) $\mathrm{MgSO}_{4}$ etkisine maruz kalan örneklerin birim hacim ağırlık değerleri.

Çimento kimyasalının sülfat hücumunda etkisi önemli olmakla birlikte sülfat hücumunu önlemede tek başına yeterli değildir. Sülfat hücumunun etkisinin azaltılabilmesi için çimento içerisinde bulunan $\mathrm{C}_{3} \mathrm{~A}$ miktarının az olması gerekmektedir. Aynı zamanda hazırlanan matrisin geçirimliliğinin de düşük seviyelerde olması gereklidir. Bunun yanında çimentoya yapılan mineral katkıların sülfat etkilerini azalttığı belirtilmektedir (Ilıca 2008). Bu bilgiler doğrultusunda ve üretimde kullanılan çimentonun portland kompoze çimento olduğu düşünüldüğünde örneklerde büyük bir dayanım kaybı beklenmemiş ve elde edilen bulgular Şekil 5'de gösterilmiştir.
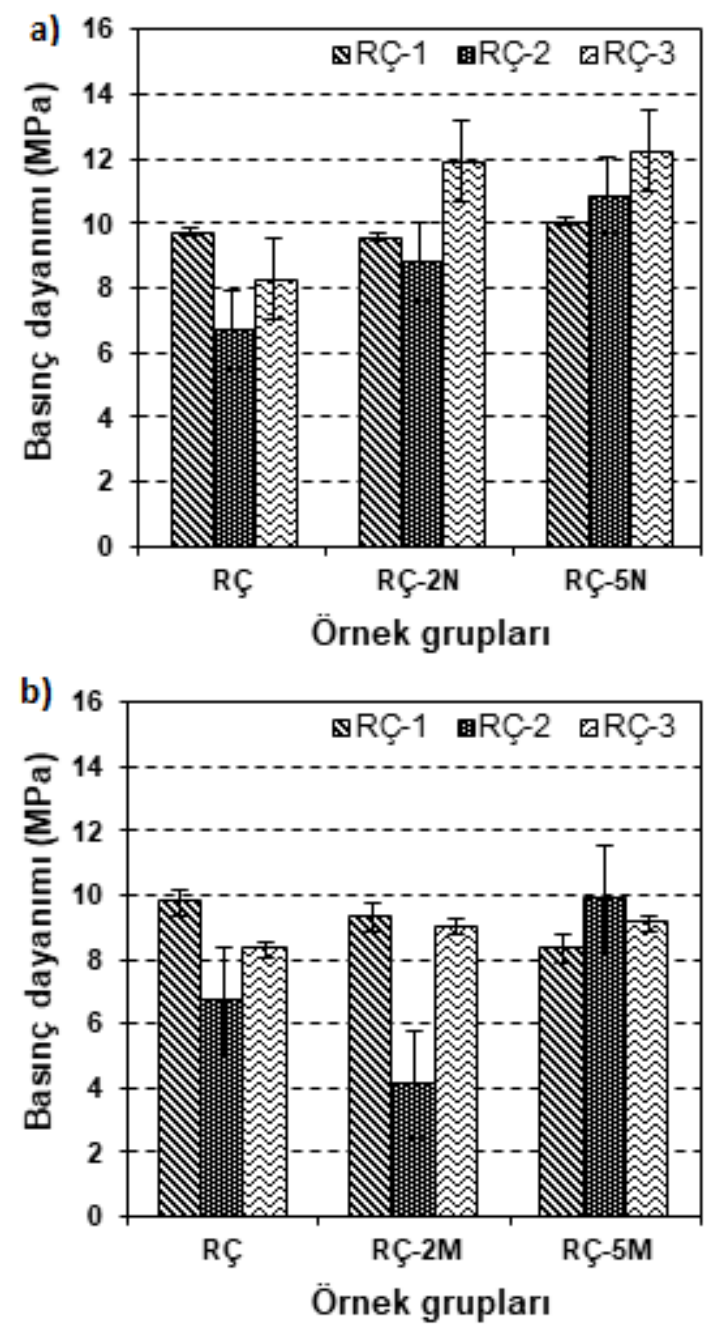

Şekil 5. a) $\mathrm{Na}_{2} \mathrm{SO}_{4}$ etkisine, b) $\mathrm{MgSO}_{4}$ etkisine maruz kalan örneklerin basınç dayanım değerleri.

Sürekli sülfat etkisine maruz kalan numunelerin, ıslanma-kuruma çevrimine maruz kalan örneklere kıyasla basınç dayanımlarının daha yüksek seviyelerde olduğu ve sürekli sülfat ortamlarında tekrarlı kristalleşme olmaması nedeniyle basınç dayanımının daha yüksek olması sonucunu ortaya çıkaracağı belirtilmiştir (Güneyisi vd. 2007). Çalışmada örneklere uygulanan sülfat etkisinin sürekli bir etki olduğu düşünüldüğünde SEM çekimlerinde de görüldüğü üzere bünye morfolojisinde önemli olabilecek çatlak gelişimi gözlenmemiştir. 
Sülfatlı Ortamda Kür Edilen Kirec - Alç - Cimento Kompozit Malzeme Özelliklerinin Araștırılması, Görhan vd.

Literatürden elde edilen bilgilere göre kireç harcına

çimento ilavesi yapılması durumunda karışımın su ihtiyacının arttığı belirtilmektedir. Kireç harcı içerisinde bulunan çimento, aktif silisyum dioksit ve alüminyum oksidi önemli ölçüde arttırmaktadır. Bu sayede kireç harcının su direnci sağlanırken mekanik özellikleri de artmaktadır (Gulbe et al. 2017).

Bu sebeple referans kompozit malzemelerde (RÇ-1) en yüksek kireç oranına sahip olan örneklerin en yüksek dayanım değerine sahip olduğu düşünülmektedir (9.8 MPa). Bununla birlikte, kireç oranı azalmasına bağlı olarak örneklerin basınç dayanımlarda lineer bir azalma gözlenmemiştir. Yapılan başka bir çalışmada ise kireç esaslı harçlarda \% 40'a kadar çimento eklenmesi durumunda mekanik dayanımın hafifçe artacağı, çimento harçlarında ise kireç eklenmesi durumunda mekanik dayanımların önemli oranda azalacağı belirtilmektedir (Arandigoyen and Alvarez 2007).

$\mathrm{Na}_{2} \mathrm{SO}_{4}$ çözeltisine maruz kalan örneklerde bünye matrisi içinde bulunan alçı oranının ve çözelti konsantrasyonunun artması ile birlikte örneklerin basınç dayanım değerlerinde artışlar olduğu belirlenmiştir. En yüksek basınç dayanımına (10 12.2 $\mathrm{MPa}$ ) sahip olan kompozit malzeme grubunun, \% $5 \mathrm{Na}_{2} \mathrm{SO}_{4}$ çözeltisine maruz kalan örnekler olduğu gözlenmiştir (Şekil 5a). Bununla birlikte, kireç ikame oranı arttığında örneklerin basınç dayanımlarında azalmalar olduğu daha önce yapılan bir çalışmada da belirtilmektedir. İlgili çalışmada temelde magnezyum sülfat çözeltisine maruz bırakılan harç örneklerinde, sodyum sülfata maruz kalan örneklere göre daha düşük basınç dayanım değerleri elde edildiği, uzun periyotlarda ise örneklerde meydana gelen dayanım kayıplarının kireç oranına büyük ölçüde bağlı bulunduğu belirtilmiştir (Lee et al. 2008).

$\mathrm{MgSO}_{4}{ }^{\prime}$ In örneklerde sadece alçı taşı ve etrengit oluşumu sağlamadığı; bununla birlikte çimentolu ürünlerin meydana getirdiği $\mathrm{C}-\mathrm{S}-\mathrm{H}$ jelleri ile reaksiyonlara girerek bağlayıcılık değeri olmayan kristal magnezyum silikat oluşuma yol açtıkları (Erdoğan 2003) ve bu sebeplerden ötürü malzeme dayanımlarında kayıplar oluşabileceği belirtilmektedir.

Şekil $5 b^{\prime}$ de elde edilen veriler incelendiğinde ise literatürde belirtilen benzer sonuçlara ulaşıldığı ve $\mathrm{MgSO}_{4}$ çözeltisine maruz kalan kompozit malzemelerde basınç dayanım değerlerinin $\mathrm{Na}_{2} \mathrm{SO}_{4}$ çözeltisine maruz kalan örneklere kıyasla daha düşük seviyelerde olduğu görülmüştür.

\section{Sonuçlar}

Sülfatlı ortamların kireç-çimento-alçı kompozit malzeme özelliklerine yapacağı etiklerin araştırıldığı bu çalışmada elde edilen bulgulara göre; genel olarak çözelti konsantrasyonu artışı ile örneklerin porozite ve su emme oranlarının azaldığı, $\mathrm{MgSO}_{4}$ çözeltisine maruz kalan örneklerde ise su emme ve porozitenin bir miktar daha fazla olduğu belirlenmiştir.

90 gün farklı solüsyonlarda bekletilen örneklerin yüzeylerinde çatlaklar gözlenmesine rağmen bu çatlakların yüzeysel olduğu ve 500x büyütmeli SEM görüntülerinde de malzeme içyapısında önemli bir çatlak gelişimi oluşmadığı gözlenmiştir. Bununla birlikte bünye içerisinde entrenjit mikro kristallerinin de bulunduğu düşünülmektedir.

$\mathrm{Na}_{2} \mathrm{SO}_{4}$ çözeltisine maruz kalan örneklerin birim hacim ağırlıklarının ve basınç dayanım değerlerinin daha yüksek seviyelerde olduğu bununla birlikte karışımlarda bulunan alçı miktarının ve konsantrasyonun artmasıyla basınç dayanımlarında olumlu artışlar olduğu gözlenmiştir. Aynı zamanda $\mathrm{Na}_{2} \mathrm{SO}_{4}$ konsantrasyon oranının artmasıyla ilgili örneklerin basınç dayanımları artmıştır. Bu noktada hazırlanan iki farklı sülfat çözeltileri birbirleriyle kıyaslandığında $\mathrm{MgSO}_{4}$ çözeltisine maruz kalan örneklerde dayanım gelişimi daha düşük seviyelerde gerçekleşmiştir.

Sonuç olarak hazırlanan kompozit malzemelerin $\mathrm{Na}_{2} \mathrm{SO}_{4}$ etkisinden daha az etkilendiği ve $\mathrm{Na}_{2} \mathrm{SO}_{4}$ çözeltisine maruz kalan örneklerin basınç dayanımlarının 8.8 - $12.2 \mathrm{MPa}$; $\mathrm{MgSO}_{4}$ çözeltisine maruz kalan örneklerin basınç dayanımlarının ise 4.1 - 9.1 MPa arasında değişkenlik gösterdiği tespit edilmiştir. Aynı zamanda $\mathrm{MgSO}_{4}$ etkisine maruz 
kalan kompozit malzemelerde \% 30 oranında kireç

kullanılması durumunda referans örneklerden daha iyi bir basınç dayanım değerleri elde edilmiştir.

\section{Kaynaklar}

Akın, E. S., Hanoğlu, C., 2013. Tokat Geleneksel Konut Mimarisi'nde íç Mekan Alçı Süslemeleri. Vakıflar Dergisi. 40, 163-184.

Aktürk, B., Ulukaya, S., Kizilkanat, A. B., Yüzer, N., 2017. Yüksek Fırın Cürufu Esaslı Harçların Sıva Olarak Tarihi Yapılarda Kullanılabilirliğinin Araştıııması. Uluslararası Katıımlı 6. Tarihi Yapıların Korunması ve Güçlendirilmesi Sempozyumu, 559-569.

Arandigoyen, M., Alvarez, J. I., 2007. Pore structure and mechanical properties of cement-lime mortars. Cement and Concrete Research. 37, 767-775.

ASTM C1012 / C1012M-18b, 2018. Standard Test Method for Length Change of Hydraulic-Cement Mortars Exposed to a Sulfate Solution, ASTM-USA.

Erdoğan, T. Y., 2003. Beton, 1. Baskı, Metu Press, Ankara, 26-665.

Erten, E., 2009. Deniz suyunun çimento tipi farklı harçların mekanik ve durabilite özelliklerine etkisi, Yüksek Lisans Tezi, DEÜ Fen Bilimleri Enstitüsü-izmir, 259.

Gulbe, L., Vitina, I., Setina, J., 2017. The Influence of Cement on Properties of Lime Mortars. Procedia Engineering. 172, 325-332.

Gümüş, A., 2016. Geopolimer Beton Özelliklerine Termal Kür Prosesinin Etkisi, Yüksek Lisans Tezi, Afyon Kocatepe Üniversitesi, Fen Bilimleri Enstitüsü, Afyon, 84.

Güneyisi, E., Gesoğlu, M., Mermerdaş, K., 2007. Metakaolin Katkılı Betonların Sülfat Dayanıklılı̆ının İncelenmesi. 7. Ulusal Beton Kongresi, 259-270.

Hartshorn, S. A., Sharp, J. H., Swamy, R. N., 1999. Thaumasite formation in Portland-limestone cement pastes. Cement and Concrete Research. 29, 13311340.

Huang, Y., Guan, Y., Zhou, J., Ge, Z., Hou, Y., 2018. Characterization of mortar fracture based on three point bending test and XFEM. International Journal of Pavement Research and Technology, 11, 339-344.

llıca, T., 2008. Farklı Çimentolarla Üretilen Betonlarda Sülfat Etkisi Ve Klorür Geçirimliliği, Yüksek Lisans Tezi, İstanbul Teknik Üniversitesi Fen Bilimleri Enstitüsü, İstanbul, 170.
Jaafri, R., Aboulayt, A., Alam, S. Y., Roziere, E., Loukili, A., 2019. Natural hydraulic lime for blended cement mortars: Behavior from fresh to hardened states. Cement and Concrete Research. 120, 52-65.

Lanas, J., Alvarez-Galindo, J. I., 2003. Masonry repair limebased mortars: factors affecting the mechanical behavior. Cement and Concrete Research. 33, 18671876.

Lee, S. T., Hooton, R. D., Jung, H.-S., Park, D.-H., Choi, C.S., 2008. Effect of limestone filler on the deterioration of mortars and pastes exposed to sulfate solutions at ambient temperature Cement and Concrete Research. 38, 68-76.

Li, L. G., Wang, Y. M., Tan, Y. P., Kwan, A. K. H., Li, L. J., 2018. Adding granite dust as paste replacement to improve durability and dimensional stability of mortar. Powder Technology. 333, 269-276.

Moropoulou, A., Bakolas, A., Moundoulas, P., Aggelakopoulou, E., Anagnostopoulou, S., 2005. Strength development and lime reaction in mortars for repairing historic masonries. Cement and Concrete Composites. 27, 289-294.

Nayaka, R. R., Alengaram, U. J., Jumaat, M. Z., Yusoff, S. B., Alnahhal, M. F., 2018. High volume cement replacement by environmental friendly industrial byproduct palm oil clinker powder in cement - lime masonry mortar. Journal of Cleaner Production. 190, 272-284.

Stolz, C. M., Masuero, A. B., 2018. Influence of grains distribution on the rheological behavior of mortars, Construction and Building Materials. 177, 261-271.

Tekin, Ç., Kurugöl, S., 2012. Çeşitli Organik Katkıların Kirecin Karbonizasyonu Üzerindeki Etkisi. Gazi Üniversitesi Mühendislik-Mimarlık Fakültesi Dergisi. 27, 717-728.

TS EN 196-1, 2016. Methods of testing cement - Part 1: Determination of strength, TSE, Turkey.

TS EN 197-1, 2002. Cement- Part 1: Compositions and conformity criteria for common cements, TSE, Turkey.

TS EN 771-1, 2005. Specification for masonry units - Part 1: Clay masonry units, TSE, Turkey.

TS EN 772-4, 2000. Methods of test for masonry units Part 4: Determination of real and bulk density and of total and open porosity for natural stone masonry units, TSE, Turkey.

Yildiz, S., Yalinbaş, M., Keleştemur, O., 2006. Silis Dumanı Katkılı Yapı Alçılarında Basınç Dayanımııın 
Araştırılması. Uludağ Üniversitesi MühendislikMimarlık Fakültesi Dergisi. 11, 15-21.

Wongprachum, W., Sappakittipakorn, M., Sukontasukkul, P., Chindaprasirt, P., Banthia, N., 2018. Resistance to sulfate attack and underwater abrasion of fiber reinforced cement mortar. Construction and Building Materials. 189, 686-694. 